\title{
Recreational benefits of wetlands: a survey on the Dal Lake in Jammu and Kashmir of India
}

\author{
Showkat Ahmad Shah \\ Mizan-Tepi University, Mizzan, Ethiopia, and \\ Md. Saiful Islam \\ University of Hail, Hail, Saudi Arabia
}

Recreational benefits of wetlands

Received 10 March 2021 Revised 2 June 2021 Accepted 12 July 2021

\begin{abstract}
Purpose - A wetland is a place of tourist attraction, and tourism values play a key role in economic development. Among various services provided by a wetland, recreational services are increasingly valuable in the tourism sector. This paper aims to unfold the potential recreational values of the Dal Lake in Jammu and Kashmir, India.

Design/methodology/approach - The study uses individual travel cost methods (TCMs) and assesses its impact on regional development in terms of income and employment generation. A sample of 200 tourists is selected through an on-site survey on Dal Lake, and the demand for recreational visits and its value is estimated by employing the truncated Poisson regression model (TPRM) and un-truncated Poisson regression model (UTPRM). The consumers' surplus is estimated and tourists' benefit to visiting the wetland is explored.

Findings - On average, estimated consumers' surplus per visitor is Rs 6,250 (US\$96.15) and Rs 25,000 (US\$384.61) from respective models. The annual total recreational value of the lake is accounted for Rs $1713 \mathrm{~m}$ (US\$26m). This high consumer surplus (CS) and recreational values of the lake indicate large demand for its recreational facilities.

Originality/value - The study is based on primary data and thus, is original. The paper has implications for the policymakers to formulate sustainable management plans for the proper use of Dal Lake and tourism development.
\end{abstract}

Keywords Recreational benefits, Economic assessment, Travel cost method, Count data models, Dal lake, Kashmir

Paper type Research paper

\section{Introduction}

A wetland is a place of tourist attraction that is described as a productive ecosystem, which provides several services including food, habitat for fish, plants, wildlife, flood protection, erosion control, water purification, carbon sequestration and opportunities for recreation, environmental and cultural education and research (DeGroot et al., 2006; Barbier et al., 2011). Besides, a wetland also provides several direct and indirect use values. It serves as a source of employment and income. People use wetlands for agriculture farming, fishing for home and commercial purposes, trees for timber and fuelwoods and reeds to make mats and thatch roofs in village houses. Thus, a wetland ecosystem provides invaluable environmental, economic and recreational benefits to society.

Schuyt and Brander (2004) based on 89 case studies reported that Asian wetlands accounted for US\$1.8bn per year in an absolute term out of US\$3.4bn per year in the world,

(C) Showkat Ahmad Shah and Md. Saiful Islam. Published in International Hospitality Review. Published by Emerald Publishing Limited. This article is published under the Creative Commons Attribution (CC BY 4.0) licence. Anyone may reproduce, distribute, translate and create derivative works of this article (for both commercial and non-commercial purposes), subject to full attribution to the original publication and authors. The full terms of this licence may be seen at http://creativecommons.org/licences/by/4.0/ legalcode

Declaration: There is no conflict of interest.

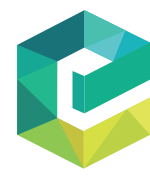

International Hospitality Review 
and millions of hectares of these wetlands were used for agricultural activities. Although in developing countries like India there is a paucity of full information about wetlands, several studies indicate that a major proportion of the Indian population obtain their livelihood and maintain the economy through using different wetlands and their resources (Anonymous, 1993). Bassi et al. (2014) documented that about $61 \%$ of total fish production was derived from inland wetlands in the Orissa state of India. The study highlighted that the wetlands surrounded by the mangrove forest protected the countryside and minimized the losses to US $\$ 33.31$, and in the absence of mangrove forest protection, the losses could be US $\$ 153.75$ per household. A study on Ramsar-site Tsomoriri wetland (Ladakh) in north India highlighted that people earned US\$ 700-1200 in the summer season annually (Anand et al., 2012).

Nature-based tourist places such as wetlands and natural reservoirs are the sources of economic thrust as they attract an influx of tourists. Do et al. (2015), for example, reported that about 21 million tourists visited four wetlands from 2007 to 2012 in South Korea, which led to a large proportion of tourism activities in this region. Based on the survey of ten protected areas, Karanth and DeFries (2011) summarized that nature-based tourism is an emerging industry in terms of providing employment, resource use and other best practices in India. The study also reported that nature-based tourism documented a $15 \%$ growth rate, $80 \%$ of which were domestic tourists.

The contribution of the tourism sector to income growth and employment generation is well-recognized in many developing countries. Therefore, the preservation and management of natural recreational sites such as wetlands are crucial pre-condition to determine the volume of tourism and recreational activities at the site. Wetlands like coral reefs, lakes, reservoirs, etc. are considered critical instruments for tourist attraction in any country (Wetlands Conservation and Management Rules, 2017). These are involved in various income generation activities such as tourist guides, boat transporters, fishing and vendors. Basu and Maertens (2010) had reported that tourism had great potential for income growth and employment generation in India. The tourism sites in the Jammu and Kashmir region of India particularly generate immense economic benefits through attracting national and international fascination. From antiquity to the present, natural resources such as lakes, mountains, landscapes, forests and waterfalls of the state have been contributing a lot to boost up the tourism industry in the country.

The Kashmir region has huge tourism potential and a leading edge of development. Centuries ago, the Mughal emperor Jahangir was exclaimed by its beauty and conferred "If there is paradise on Earth, it is this, it is this, it is this" (Lawrence, 2005; Raina, 2014). Kashmir looks like a paradise because of its bestowed scenic beauty, rich flora and fauna, wildlife sanctuaries, snow-clad mountains and wetlands. Tourists from different parts of the world are fascinated to visit Kashmir to enjoy its scenic beauty and gain recreational benefits. It prevails as a significant place throughout the whole region of Hindu Kush Himalaya. Consequently, the tourism sector contributes to the state's revenue, generates employment opportunities and accounts for $6.68 \%$ of the state's gross domestic product (Economic Survey, 2017).

Among many scenic beauties and tourist sites in the state, the significance of the Dal Lake is paramount and its contribution to the tourism sector is enormous. Its location, scenic beauty, enchanting environment, floating gardens, Shikara (small decorative boats) and houseboat services make the lake more attractive, significant and distinct as compared to other wetlands and tourist places. The tourists become very enthusiastic and spend a lot of time and money to enjoy its natural beauty and services. The lake occupies a crucial place in the valley, as its physical setting is more attractive than other lakes. Moreover, adjacent to its periphery, many tourist attraction spots such as Mughal gardens (such as Nishatgarden, Shalimar garden, Cheshma Shahi and Pari Mahal), botanical garden and different religious 
shrines like Hazratbal shrine, Shankaracharya temple and Makhdoom Sahib are built. Moreover, the lake is famous for its strength in sustaining ecological balance within its periphery through different species of flora and fauna at different levels of water and different times of the year (Trisal, 1992).

Despite its socio-cultural, ecological and economic importance, the existence of the lake is under threat mainly due to various anthropogenic stresses by increasing population, encroachment, domestic and commercial pollution and increasing agricultural activities by local inhabitants. Besides, tourism intervention also leads to mixed effects that may either benefit the communities or degrade the ecosystem. Meleddu (2014) highlighted that both positive and negative externalities of tourism affect the local people at their destination. Therefore, the Dal Lake being one of the Himalayan lakes has become fragile in its ecosystem; its existence is at stake due to increased human intervention, which needs to be minimized to conserve the lake and ensure its sustainability. Hence, this study aims to assess the recreational benefits of the lake by highlighting its tourism values; and to enlighten the policymakers to ensure its sustainable use and conservation of this scenic-natural resource having socio-cultural and ecological importance.

\subsection{Profile of the study area}

The Dal Lake is a Himalayan urban freshwater, multiple basin oxbow lake, which has a great tourist attraction. The lake is famous for its both attributes, i.e. beauty and ecological significance. It is located in the summer capital, Srinagar, of Jammu and Kashmir, India. Its

$\mathrm{F} 1$ location map is demonstrated in Figure 1. It lies between $34^{\circ} 06^{\prime} \mathrm{N}$ and $74^{0} 52^{\prime} \mathrm{E}$ at an elevation of $1587 \mathrm{~m}$ above sea level. It has an area of about $1670 \mathrm{ha}$, a total catchment of about $317 \mathrm{sq}$. $\mathrm{km}$, divided into five sub-catchments (Shah, 2012). Based on early causeways and projecting marshy lands, the lake is divided into three parts: Lokut-Dal (Little Dal), Bod-Dal (Big Dal) and Soderkhan. Thousands of households live in and around the lake and depend directly or indirectly on it for their livelihoods.

The lake attracts tourists from different parts of the world with its unique features, namely, floating gardens, angling and bird-watching. Out of the total fish catch from the lake, 60-70\% includes exotic carp. Many tourist attraction spots are situated on the lake site. Thus, increasing population, encroachments, domestic and commercial pollution, increasing agricultural activities, eutrophication and weed infestation threaten its existence. Every year, thousands of canals [1] of the open water area of the lake are converted into floating gardens and other landmasses (Kundanger, 2012). Experts opine that the lake may disappear within the next 50 years due to ever-increasing eutrophication and siltation. This heavy load of nutrients comes mainly from Srinagar city, Dachigam and Telbal sub-catchments (Ahmedullah, 1997).

Several programs and proposals were initiated from time to time for the conservation of the lake. These, however, have not yielded any dividend. Numbers of studies and reports have evaluated the impact of these programs; an overriding conclusion of these studies is that the lake is under serious anthropogenic stress causing both reversible and irreversible damage to it. These threats thus need sustainable solutions.

The present study aims to examine the socio-economic determinants of tourists' visits to the site and estimate the recreational benefits (tourism value) and consumer surplus (CS) that accrue from the lake and bring them to the notice of the policymakers so that they would be able to know the economic importance of the lake and ensure its sustainable use and conserve this scenic-natural resource. The remaining parts of the study are organized as follows. The 2nd section discusses the literature review, the 3rd section describes the data and methodology of the study, the 4th section analyses the results and finally, the 5th section concludes the study.
Recreational benefits of wetlands

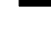


IHR

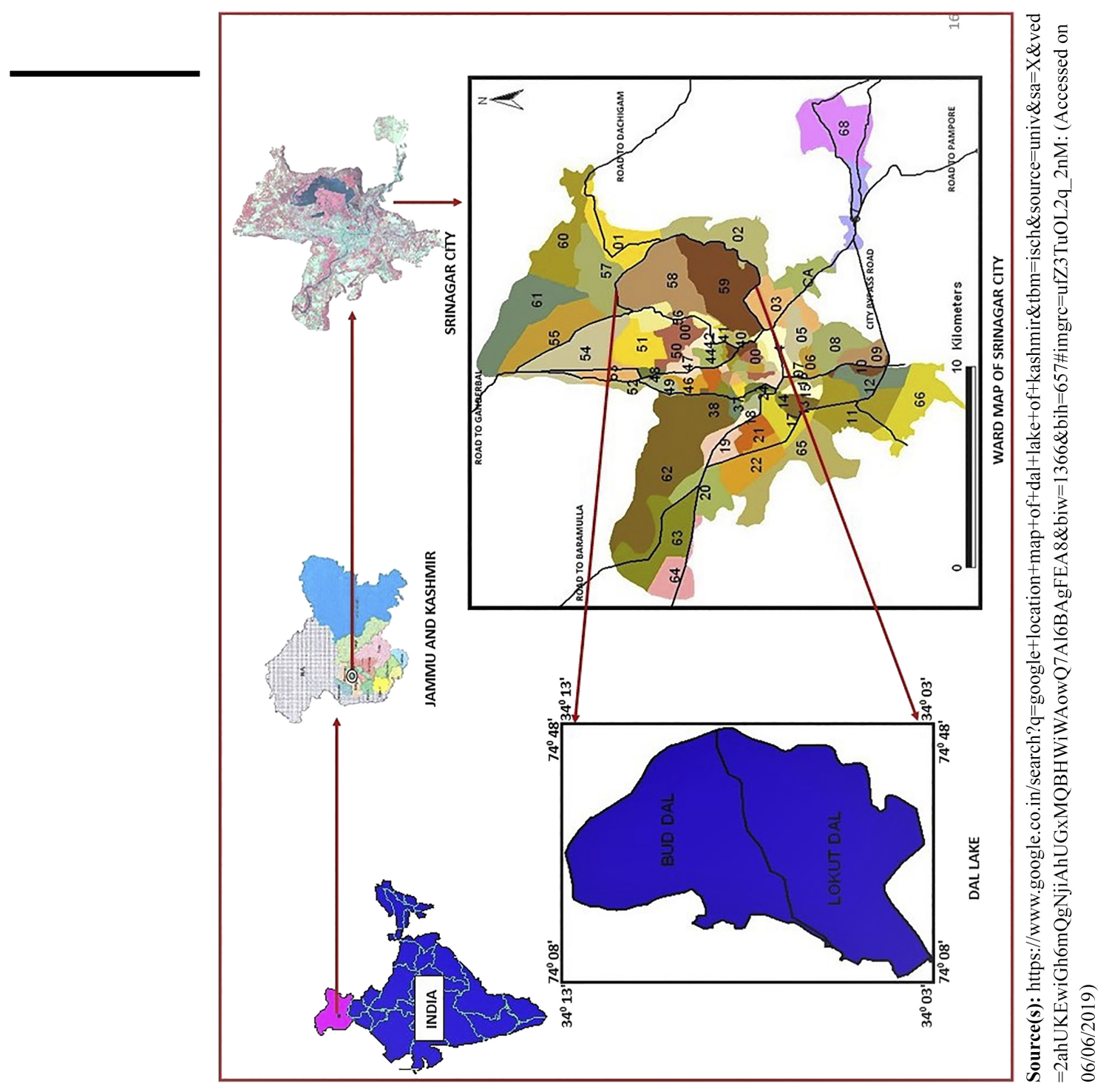

Figure 1.

Location map of

Dal Lake 


\section{Literature review}

Many studies have attempted to estimate recreational values, biodiversity values, computed welfare loss of natural sites and recreation management and planning. Bell and Leeworthy (1990) assessed the role of a spatial divergence of tourists coming from different places to visit the Florida beach to have recreational joys. The study employed an on-site cost demand curve for tourists, estimated the daily CS to be US $\$ 34.00$ for the beach resources. Ward and Beal (2000) believed that some visitors made trips on holidays and faced no loss of income. Therefore, they recommended a zero (or no) value of time to be included in the estimation of the recreational demand function. They opined that it would underestimate the recreational value and CSs in case of working days visitation, and the zero opportunity cost of time could only be true for visitors such as students, unemployed and retirees. Ortacesome et al. (2002) estimated the recreational value of the Kursunlu Waterfall National Park in Turkey and recommended more studies be conducted to quantify the different environmental benefits, which would enable policymakers to make proper management and conservation decisions for environmental resources.

Kousmanen $e t$ al. (2004) applied the zonal travel cost method and estimated the benefits of Bellenden Ker National Park, Australia. They argued that treating a multi-destination as a single-destination trip did not show any biased CS and concluded that there would be an overestimation of the CS while discounting the multi-destination trips. Lew and Larson (2005) used a discrete-choice recreation demand model for San Diego beach users and estimated a stochastic shadow value of time function and derived further precise welfare estimates from leisure demand models.

Tapsuwan et al. (2007) investigated the impact of groundwater overuse in Western Australia. Several nearby wetlands' water was the main source of potable water to this area, and enormous consumption led to a decline in groundwater and caused climate change. Using the Hedonic property price approach, they estimated the value of wetlands in the Perth metropolitan region, and revealed that the value of the area was increased by AU $\$ 463$ if the distance was is reduced by $1 \mathrm{~m}$ from the nearest wetland; if there were more than one wetland within 1.5 kilometers of a property, it would help to increase the property price by AU $\$ 6,081$. Based on findings, the study argued that "more a wetland ecosystem was enchanting, more would be the value of surrounding property." Using the travel cost method (TCM), Gurluk and Rehber (2008) estimated the recreational demand for Kus-cenneti National Park (KNP), Turkey. They incorporated the visitor's one-third hourly wage rate as the opportunity cost of time and estimated recreational value of KNP, which accounted for US\$103.32m annually. This value was found significantly higher than the yearly investment and other overheads of the KNP and would be socially profitable as its main policy implication. However, the main drawback of this study was that the estimation might have some overstated and understated effects.

Edwards et al. (2011) used a recreational demand function to estimate the number of recreational visits to Delaware Bay in Delaware (USA) and revealed the value of the migratory shorebirds. The estimated annual bird-watching use value was accounted to be US $\$ 215,000$ based on the predicted visits of households. Islam et al. (2011) discussed community-based ecotourism in the Sundarbans of Bangladesh, which is the largest mangrove forest in the world. The local community people surrounding the Sundarbans are involved in several ecotourism activities such as selling local handicraft products, cultural shows, amusement recreation events and tour guides. The study revealed that ecotourism had some positive impact on the economic life of their community, while it harmed the culture and traditions of the local community.

Bhatt et al. (2014) estimated the economic value of preserving the biodiversity of manmade wetlands (Pong Dam) of Himachal Pradesh, India. They used a contingent valuation survey method for collecting responses from the respondents and found the estimated mean
Recreational benefits of wetlands 
willingness to pay (WTP) to be Rs 75 and Rs 368 per year using single-bounded dichotomous choice and open-ended WTP format, respectively. The study also explored that Pong Dam provided a habitat for rare international migratory birds, and its recreational value for tourists was increasing every year. Their study implications visioned that if its biodiversity could be preserved, the wetland could serve as an international tourist destination for birdwatchers. Jeoffrey and Sandrine (2014) examined the combining effect of multivariate and cost analysis for 91 beaches in southwestern France. Results showed that multivariate analyses provided a better understanding of the functioning of sites, assessment of the current environmental and social conditions, while cost analysis aimed at giving a full account of the variability of management costs at the site level. The combining results of the study would propose an alternative integration path, namely the "no social cost" path.

Jala and Nandagiri (2015) evaluated the recreational values of Pilikula Lake, Mangalore, India using cross-section data and applying the travel cost method (TCM) and contingent valuation method (CVM) and revealed a higher value of estimated mean WTP following TCM compared to CVM. The CS was calculated Rs 17,857 per day, while the net benefit per individual visit was estimated at Rs 238.

Voltaire et al. (2016) used a zonal TCM and estimated the value of recreational trips to a coastal site in France. They highlighted the potential effects on CS and concluded that people were willing to pay a socially acceptable amount of money for its preservation, which in turn would increase the welfare of people. Lamsal et al. (2016) used both TCM and CVM to determine the recreation potential and to calculate WTP by tourists as entry fees of the Ghodaghodi Lake Complex, Nepal. They found per visitor average travel cost to be US $\$ 7.71$ and US\$ 0.48 per visit mean WTP an entry fee. Thus, estimated the annual recreational potential of the lake amounted to US $\$ 0.054 \mathrm{~m}$. This provided an opportunity to learn what the local community expected, also helped to analyze and prioritize the visitors' requirements for tourism growth and expansion.

Using the trip generation function (TGF), Rao and Balasubramanian (2017) applied the Poisson regression model and investigated the total recreational value of Kuttanad Coastal Wetland, Kerala, India. They estimated the annual recreational value to be Rs $230.57 \mathrm{~m}$ and Rs 769.23 per visit CS. The estimated huge recreational value of the wetland emphasized the need for sustainable management and conservation of the wetland and directed the policymakers to do the needful. Pokki et al. (2018) estimated the recreational value of salmon fishing in the Teno river area using a travel cost recreation demand model. Their estimation explored the sustainable management of salmon stock in the river, and the study was significant not only from the conservation point of view but it also highlighted the increased recreational benefits of the site. This generated the income for locals as recreational fishing tourism. The estimated CSs from the survey data would indicate that recreational angling had a substantial welfare effect on anglers on the study site. The study also suggested the river management body to estimate the economic benefits from the processes to store the migratory fishes by using their CS estimates.

Zarandi et al. (2019) applied a contingent valuation approach and logit model to estimate visitors' WTP for the Kanibrazan wetland, Iran and concluded that socio-economic variables of the tourists had a significant effect on the likelihood of visitors WTP for recreation. The estimated average WTP per visitor accounted for 38,217 Iranian Rials (US\$1). The estimated recreational value of the wetland induced the authorities to hand over its management and protective measures under the hands of the private and local community so that the tourist influx rate to the wetland could increase ahead. Yrgalem and Mekonnen (2019) estimated the recreational value of Ziway Lake in Ethiopia, based on a survey of on-site 223 visitors. Using the truncated Poisson regression model (TPRM), they estimated the annual recreational value per visit per person US\$ 114.41 , and the total annual recreational value of the site US\$ $4.05 \mathrm{~m}$. Li et al. (2020) evaluated the wetland ecosystem services provided by national nature reserves 
in several coastal provinces/municipalities in China. The reported a total value of $33.168 \mathrm{~b}$ US $\$$ per year accruing from wetland ecosystem services in 35 national nature reserves.

In addition, several studies have investigated the Dal Lake in terms of biological and sociological points of view such as causes of degradation of water quality, extinction of endangered species of the lake, tourism satisfaction, lake conditions, mapping of land use/ land cover and problems and prospects of the lake (Trisal, 1992; Sheikh et al., 2008; Shah, 2012; Khan, 2015; Yousuf and Ali, 2018). The above-cited studies enlightened several aspects of tourism including the recreational benefits of tourists' places using different methodologies. The main conclusion of these studies is that natural and man-made recreational sites have potential economic values, and if they are maintained and improved sustainably, these will increase the people's welfare. Following a similar pattern, this study aims to assess the recreational benefits and CSs from Dal Lake. Being one of the prominent north-western Himalayas wetlands, the Dal Lake is yet to be studied from the economic perspective. This wetland has potential recreational values, but to the best of the authors' knowledge, there is no study done yet to assess its recreational values. Therefore, the present study aims to estimate the recreational benefits and CSs from the lake that will add to the existing literature.

\section{Data and methodology}

The study was based on a primary survey, which followed a random sampling technique. The survey was conducted in July-October, 2017. The on-site tourists, who directly benefited from the recreational services of the lake, were targeted as the active population of the survey. A total of 200 tourists were surveyed randomly through face-to-face interviews employing trained enumerators. A pre-tested structured questionnaire was used as an instrument of data collection. The questionnaire had four parts. The first part covered the demographic and socio-economic profile of the visitors; second part included the key questions related to the origin of the visitors, mode of journey, travel time, on-site time spent and travel expenditures. The third part contained questions related to the visitor's on-site activities such as birdwatching, boat riding (Shikara), recreational fishing and sightseeing; expenditure, and time spent on these activities. The fourth and final part has pertained to respondents' perceptions of the current situation of the site. It also includes their suggestions and preferences for facilities improvements. The study was supplemented by secondary data from various published and unpublished sources such as "Economic Survey of Jammu and Kashmir," reports of Lakes and Water Ways Development Authority and Jammu and Kashmir census reports.

Cronbach's alpha test based on Cronbach (1951) was conducted to test the reliability and internal consistency of collected data.

The commonly used assessment methods to estimate the value of recreational sites are the contingent valuation method (CVM), TCM, choice modeling and hedonic method (Bakhsh et al., 2019). However, in assessing the recreational values of the wetlands, the TCM has been used extensively (Edwards et al., 2011; Lamsal et al., 2016). Therefore, this study employed the TCM for achieving the set objectives. In TCM, an individual's recreation value depends on the number of visits of the visitors, quality of the site and other goods. The single-site individual travel cost model was applied to estimate recreational value. The following trip generation function (TGF) was formulated based on Garrod and Willis (1999).

$$
\mathrm{NV}_{i j}=f\left(\mathrm{RTTC}_{i j}, Q_{i j}, S_{i}, Y_{i}\right)
$$

where $i=1,2,3, \ldots n$.

$\mathrm{NV}_{i j}=$ Number of visits made by an individual " $i$ " to site " $j$ " in the last year;
Recreational benefits of wetlands

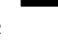


$\mathrm{RTTC}_{i j}=$ Round total travel cost excluding time cost incurred by an individual " $i$ " to site " $\mathrm{";}$

$Q_{i j}=$ Vector of environmental qualities [sightseeing $\left(Q_{1}\right)$ and fishing $\left(Q_{2}\right)$ ] of the site " $j$ ”;

$S_{i}=$ Vector of socio-demographic characteristics of the respondent " $i$ " and

$Y_{i}=$ Monthly income of the individual " $i$ ".

Eqn (1) was further specified incorporating socio-demographic characteristics of the respondents and reported in Eqn (2).

$$
\mathrm{NV}=\exp \left(\alpha+\beta_{1} \mathrm{RTTC}+\beta_{2} \mathrm{AGE}+\beta_{3} \mathrm{FLZ}+\beta_{4} \mathrm{EDU}+\beta_{5} Q_{1}+\beta_{6} Q_{2}+\beta_{7} Y+\varepsilon\right)
$$

where, $\mathrm{AGE}=$ age of the respondents, $\mathrm{FLZ}=$ their family size and $\mathrm{EDU}=$ education level of the respondents. For ease of calculation, natural logarithms were taken and reported in Eqn (3).

$$
\mathrm{Ln}(\mathrm{NV})=\alpha+\beta_{1} \mathrm{RTTC}+\beta_{2} \mathrm{AGE}+\beta_{3} \mathrm{FLZ}+\beta_{4} \mathrm{EDU}+\beta_{5} Q_{1}+\beta_{6} Q_{2}+\beta_{7} Y+\varepsilon
$$

The recreational benefits from the wetland were assessed based on the estimation of Eqn (3). Accordingly, the on-site survey was conducted to collect data on different variables as already outlined to estimate the trip generation function (TGF). Then CS was estimated via demand function as follows (Garrod and Willis, 1999):

$$
\mathrm{CS}=-\frac{1}{\beta_{1}}
$$

where, CS stands for consumer surplus, and the total consumer surplus (TCS) generated by site " $"$ " to the users during a particular period and was estimated by TCS = average CS $\times$ total number of tourist visitors to site " $"$ " during the last one year.

As the ordinary least square (OLS) regression model is inappropriate to measure TCM, count data probability distribution was used as an alternative based on the un-truncated Poisson regression model (UTPRM) and truncated Poisson regression model (TPRM) to estimate the results. Both models were employed with the Pseudo maximum-likelihood estimation approach to account for over-dispersion and under-dispersion in STATA 12.0. The Poisson probability density function was given by Eqn (5) (Cameron and Trivedi, 1998). Based on the post-estimation of the Poisson model, a test for over/under-dispersion was carried out.

$$
P\left(Y_{i}=y_{i} \mid x_{i}\right)=\frac{e^{-\lambda_{i}} \lambda i^{y_{i}}}{y_{i} !}
$$

Where $y_{i}=0,1,2,3 \ldots n$, the number of trips undertaken by each visitor during the last one year.

Parameter $\lambda_{i}=$ expected number of trips, it is assumed to be a function of variables specified in the recreation demand function. It was usually taken an exponential mean function and then log-linear form as folows:

$$
\begin{gathered}
\lambda_{i}=\exp \left(x_{i} \beta\right) \\
\ln \lambda_{i}=x_{i} \beta
\end{gathered}
$$

Where $x_{i}$ is a vector of exogenous variables and $\beta$ is a vector of parameters. The expected number of trips of a visitor during the last year was given by Eqn (8). 


$$
E\left[y_{i} \mid x_{i}\right]=\operatorname{Var}\left[y_{i} \mid x_{i}\right]=\lambda_{i}=e^{x_{i} \beta}
$$

Eqn (8) shows equal dispersion property of the Poisson regression model, i.e. conditional mean $E\left[y_{i} \mid x_{i}\right]$ is equal to the variance $\operatorname{Var}\left[y_{i} \mid x_{i}\right]$.

Since the number of the visit includes the current (no zero) visit of the respondents for the last one-year period, the expression for the conditional probability of the number of visits $(y)$ is extended in Eqn (9) to account for the truncated value of the dependent variable at zero value (Cameron and Trivedi, 1998) [2].

$$
P\left[Y_{i}=y_{i} \mid Y>0\right]=\frac{e^{-\lambda_{i}} \lambda_{i}^{y_{i}}}{y_{i} !}\left[\frac{1}{\left(1-e^{-\lambda_{i}}\right)}\right]
$$

Where, $y_{i}=1,2,3, \ldots, n$.

T1 The definitions of variables used in this study are presented in Table 1.

\section{Results and discussion}

\subsection{Descriptive statistics}

There are seven variables used in this study, and their descriptive statistics are depicted in

T2 Table 2.

The results of the Cronbach's alpha test to validate the reliability of the data are reported

T3 in Table 3 . The value of Cronbach's alpha [3] is 0.836 , which indicates that the sample data is internally consistent and reliable.

Eqn (3) is run for both un-truncated and truncated models, and the results are reported in

T4 Table 4. Un-truncated Poisson regression results show that the estimated coefficient of RTTC has an expected negative value at a $1 \%$ level of significance. The value of coefficient -0.00004 , which implies that with a thousand Rs increase in travel cost, the number of visits to the site is decreased by $0.004 \%$ holding all other variables constant. Hence, if round total travel cost from visitors' homes to the site including time cost increases the demand for recreational visits to the lake site goes down and vice-versa.

The effect of socio-demographic factors on recreational demand or the number of visits shows mixed results. The coefficient of age is found negative $(-0.0084)$, which is significant at a 5\% level, indicating a strong and negative relationship between age and the number of visits. That is, as age increases recreational demand for traveling may go down as if the younger people are more interested in traveling than the older people.

The coefficient of family size is positive but insignificant, meaning that it does not influence the recreational demand for travel in both UTPRM and TPRM. The coefficient of education (EDU) is positive and statistically significant at a 5\% significance level, which

\begin{tabular}{ll}
\hline Variable & Definition \\
\hline NV & Number of visits of a visitor to the site during last year \\
RTTC & Round total travel cost from visitors' home to the site excluding time cost \\
AGE & Age of the respondent \\
FLZ & Family size of the respondents \\
EDU & Represents respondents' education level, categorized from 0 to 6 groups (i.e. $0 \rightarrow$ illiterate, $1 \rightarrow$ \\
& primary school level, $2 \rightarrow$ middle school level, $3 \rightarrow$ high school level, $4 \rightarrow$ higher secondary school \\
$Y$ & level, $5 \rightarrow$ undergraduates and $6 \rightarrow$ postgraduate and above)
\end{tabular}

Recreational benefits of wetlands 
IHR

\begin{tabular}{lccccc}
\hline Variable & $N$ & Min & Max & Mean & Std. dev \\
\hline NV & 200 & 1 & 11 & 1.62 & 1.532 \\
RTTC (000 Rs) & 200 & 0.150 & 57.00 & 10.066 & 8.685 \\
AGE & 200 & 18 & 70 & 37.92 & 12.326 \\
FLZ & 200 & 1 & 15 & 5.19 & 2.392 \\
$Y(000$ Rs) & 200 & 1.0 & 350.0 & 32.265 & 33.632 \\
EDU $^{1}$ & 200 & 0 & 6 & 4.55 & 1.3845 \\
$Q_{1}$ & 200 & 0 & 1 & 0.985 & 0.1219 \\
$Q_{2}$ & 200 & 0 & 1 & 0.165 & 0.3721
\end{tabular}

Table 2. Note(s): ${ }^{1}$ The mean education score indicated that most of the respondents were educated; only a few of them Descriptive statistics were illiterate

Reliability statistics

Table 3. Cronbach's alpha

Reliability test result

\begin{tabular}{|c|c|c|c|c|c|c|}
\hline \multirow[b]{2}{*}{ Variables } & \multicolumn{3}{|c|}{ Un-truncated Poisson regression } & \multicolumn{3}{|c|}{ Truncated Poisson regression } \\
\hline & Coefficient & St. error & Probability & Coefficient & St. error & Probability \\
\hline RTTC & -0.00004 & $6.60 \mathrm{E}-06$ & $0.000 * * *$ & -0.00016 & 0.00003 & $0.000 * * *$ \\
\hline AGE & -0.008 & 0.0036 & $0.023^{* *}$ & -0.023 & 0.0113 & $0.038^{* *}$ \\
\hline FLZ & 0.02426 & 0.0153 & 0.113 & 0.0410 & 0.0372 & 0.27 \\
\hline EDU & 0.068 & 0.0312 & $0.028^{* *}$ & 0.159 & 0.0854 & $0.061^{*}$ \\
\hline$Y$ & 0.106 & 0.0339 & $0.002 * * *$ & 0.152 & 0.0598 & $0.011^{* *}$ \\
\hline$Q_{1}$ & 0.338 & 0.096 & $0.000 * * *$ & 13.25 & 0.7385 & $0.000 * * *$ \\
\hline$Q_{2}$ & 0.555 & 0.124 & $0.000 * * *$ & 0.728 & 0.2643 & $0.006^{* * * *}$ \\
\hline Constant & -0.189 & 0.1998 & 0.344 & -13.45 & 0.8718 & $0.000 * * *$ \\
\hline \multicolumn{7}{|c|}{ Model statistics summary } \\
\hline \multicolumn{2}{|c|}{ Wald $\chi^{2}(\mathrm{df})$} & (7) 125.4 & & & (7) 529.79 & \\
\hline \multicolumn{2}{|l|}{ Prob $>\chi^{2}$} & 0.000 & & & 0.000 & \\
\hline \multicolumn{2}{|l|}{ Pseudo $R^{2}$} & 0.1513 & & & 0.4535 & \\
\hline \multirow{2}{*}{\multicolumn{2}{|c|}{$\begin{array}{l}\text { Log-pseudo likelihood } \\
N\end{array}$}} & -263.34 & & & -145.329 & \\
\hline & & 200 & & & 200 & \\
\hline
\end{tabular}

implies education positively influences the demand for recreational visits to the lake site. Therefore, it appears from the findings that by keeping other variables constant, a one-year increase in schooling is likely to increase the number of visits by $6.8 \%$. Thus, educated people are more interested in traveling.

The coefficient of monthly income is positive (0.106) and significant at a $1 \%$ level, implying that visitors' income has a positive and significant impact on recreational demand for visits to the lake site. This finding is in line with Mangan et al. (2013) and Du Preez and Hosking (2011). The coefficients of environmental features of the lake site such as sightseeing $\left(Q_{1}\right)$ and fishing $\left(Q_{2}\right)$ are positive and highly significant at $1 \%$ level. Thus, the environmental qualities of the lake site directly influence the demand for recreational visits to the site. 
The estimated coefficients of the UTPRM 1 have turned out to be as expected in the literature. The log-pseudo likelihood value of the model is -263.339 , and the value of Wald statistics 125.4 rejects the null hypothesis of zero effects for all predictors in the model at a $1 \%$ significance level. The Pseudo $R$-square value is 0.153 , which is reasonable for cross-section data (Cameron and Trivedi, 1998). Thus, the estimated UTPRM provides a valid estimation.

The test for over/under-dispersion validated the suitability of Poisson regression models indicated by the value of " $\alpha$ " approximately equals to zero. Whenever the value of $\alpha \rightarrow 0$, gamma distribution losses its significance, and negative binomial distribution reduces to a Poisson distribution. Since the number of visits is truncated at one, this has created a truncation bias as the un-truncated model has overestimated the CS due to a relatively smaller value of the coefficient of variable RTTC. To overcome this, the TPRM is used to estimate the CS. Although the un-truncated and truncated model results are very much similar, the un-truncated model relatively better explains the variations in variables indicated by the level of significance; therefore, we have particularly explained this model's results. However, the CSs are estimated separately for both models due to upward biasedness in the un-truncated model. Moreover, the truncated model's results show more robustness as compared to the un-truncated model in terms of model statistics particularly in log-likelihood value and value of Pseudo $R^{2}$.

\subsection{Welfare estimates}

The CS per visitor per visit is calculated based on Eqn (5) and reported in Table 5. The CS per visitor is Rs 25,000 (US\$384.61) and Rs 6,250 (US\$ 96.15) using the estimated coefficient of RTTC $\left(\beta_{\text {RTTC }}\right)$ of UTPRM and TPRM, respectively. Annual CS is estimated by multiplying CS per visitor per visit by the total number of tourist visitors and is equal to Rs 5,000,000 (US $\$$ 76,923.07) and Rs 1,250,000 (US\$19,230.76) from the respective models. This indicates that the tourists derive a substantial monetary benefit from the recreational use of the lake. Thus, we can safely conclude that the lake has substantial economic value.

The total value of recreational activities (total welfare) is estimated by multiplying the annual CS per visitor by total annual tourist visitors to the lakeside. However, it is not easy to estimate the exact total welfare since tourist visitors at times are not listed properly. In 2017, about 1,050,480 tourists visited the valley for recreational purposes (Economic Survey, 2017). Out of this, based on Shah (2012) we have approximately considered 105,048 (10\% of 2017 data) tourists, who might have visited the Dal Lake as on-site tourists in 2017 [4]. Using this number as a proxy for the tourists' inflow into the lake for the year 2017, we have calculated the total consumer surplus (TCS) to be Rs $656.55 \mathrm{~m}$ (US\$10.10m) and Rs $2626.20 \mathrm{~m}$ (US\$ 40.40) $\mathrm{m}$ per annum for TPRM and UTPRM, respectively. The total consumer surpluses (TCSs) obtained from the UTPRM show an upward bias as compared to the TPRM due to the truncation effect. This shows that the estimated CS increases as the coefficient of travel cost decrease to overcome the problem of endogenous stratification [5] of the study, which is supported by studies such as Martinez and Hilbe (2008) and Melichar (2011).

\begin{tabular}{lll}
\hline & Un-truncated Poisson model & Truncated Poisson model \\
\hline$\beta_{\text {RTTC }}$ & -0.000040 & -0.00016 \\
CS/visit per visitor & Rs 25,000 (US\$ 384.61)* & Rs 6,250 (US\$96.15)* \\
Total annual consumer surplus of dal lake & Rs 5,000,000 (US $\$ 7,69,23.07)^{*}$ & Rs 1,250,000 (US 1,92,30.76)*
\end{tabular}

Note(s): $\beta_{\text {RTTC }}=$ Coefficient of round total travel cost

*1US\$ $=$ Rs 65 , an average exchange rate during the survey period (July-October, 2017)

${ }^{\dagger}$ Based on the sample of 200 visitors
Recreational benefits of wetlands

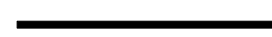


It is difficult to compare CSs for recreational values across studies due to the differences in units of measurement, change in the dollar value, variations in lengths of stay at sites, differences in methodologies and specificities of the context in which these studies have been conducted. However, in the context of the developing world, our estimates seem to be a little high. For example, Chopra (2004) estimated the CS per visit to Keoladeo National Park (India) as Rs 427.04 (approximately equal to US\$11); Okojie et al. (2013) estimated the recreational benefit of each day visit to Obudu Cattle Ranch (Nigeria) of a visitor as N380 (US\$2.34). The annual flow of benefit for each visitor estimated by Mangan et al. (2013) from the Keenjhar Lake in Pakistan was US\$28.

Our estimates, on the other hand, are lower as compared to the studies conducted in the context of the developed world. For example, the CS per person per trip from the recreational activities to Gros Morne National Park in Canada was about US\$783 (Martinez-Espineira and Amoako-Tuffour, 2008). The higher value could be related to a higher standard of living in these countries. Nonetheless, our estimates conclusively establish the economic importance of the lake.

The estimated total annual recreational value of the Dal Lake is about Rs $1713 \mathrm{~m}$ (US\$26m) for the given number of tourists $(105,048)$ as shown in Table 6 . The total expenditure incurred by the tourists either via transport or on the site and CS is expected to provide good signals to the people who depend upon tourism for their livelihood and may help them to generate additional income and employment.

\section{Conclusion}

We have examined the impact of travel cost and socio-economic characteristics of tourists on the demand for recreational tours and estimated the recreational benefits and CS from Dal Lake. The demand for recreational visits and their values are estimated using TPRM and UTPRM. It appears that travel cost is an important determinant of demand for recreational visits to the lake site; the lower the travel cost, higher is the demand for recreational visits and vice-versa. The socio-demographic factors have shown a mixed effect on recreational demand. The age of the tourists has a negative relationship to demand a site visit as if younger people are more interested in traveling than older people. The family size does not influence the recreational demand for travel. The education and income positively influence the demand for recreational visits to the lake site, meaning that people with higher income and education are more interested in recreational visits to the lake site. The features of the lake site such as sightseeing and fishing services directly influence the demand for recreational visits to the site. The truncated model has been more robust as compared to the un-truncated model as it reduces the upward bias of CS.

The CS per visitor per visit arrives at Rs 25,000 (US\$ 384.61) and Rs 6,250 (US\$ 96.15) using the estimated coefficient of RTTC $\left(\beta_{\text {RTTC }}\right)$ of the UTPRM and TPRM, respectively. The

Table 6.

Total recreational value of Dal Lake per year

\section{Consumer surplus}

Per visitor Visitors per year $(B)=\operatorname{Per}$ visitor $(C)$

(A) $\quad(A \times 105,048)$

Rs 6,250 a Rs 656,550,000

(US\$ 96.15)* (US\$10,100,769)*

Rs $10,066^{\mathrm{b}}$

(US\$154.86)*

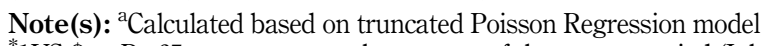

*1US $\$=$ Rs 65 , an average exchange rate of the survey period (July-October) 2017

${ }^{\mathrm{b}}$ Without the inclusion of time cost
Visitors per year $(D)=$ $(C \times 105,048)$ Rs $1,057,413,168^{\mathrm{b}}$ (US\$ $16,267,894)^{*}$
Annual recreational value

Visitors per year $(B+D)$

Rs 1,713,963,168

(US\$ 26,368,664)* 
total annual CS of tourists of the Dal Lake accounts for Rs 2626.2m (US\$ 40.40m) and Rs $656.55 \mathrm{~m}$ (US $\$ 10.1 \mathrm{~m})$ concerning respective models. In the context of the developing world, our estimates have been a little higher, while lower in the context of advanced countries. The higher values in advanced countries reflect a higher standard of living, and our estimates conclusively establish the economic importance of the Dal Lake.

The annual recreational value of the Dal Lake is estimated at Rs $1713 \mathrm{~m}$ (US $\$ 26 \mathrm{~m}$ ) for the given number of tourists $(105,048)$. Thus, a substantial monetary benefit accruing from the recreational use of the lake to the tourists indicates that the lake has substantial economic value. Even, given the normal socio-political situation in the valley, the number of tourists to the lake is likely to be higher that will lead to further economic values of the lake. The total expenditure incurred by the tourists and CS is likely to provide good indications to the local people of the valley to enhance their economic welfare. Though the study partially evaluates the economic value of the lake, the results of this study are valuable to the policymakers for formulating sustainable management plans for its judicious use and tourism development. Hence, the policymakers should invest more budgetary allocations for its betterment, conversation and proper management that will attract more tourists to the site and generate more income in one hand, and maintain an ecological balance through invaluable services such as controlling floods, storm and recharging groundwater in the other hand.

\section{Notes}

1. Canal $=\mathrm{A}$ unit of land equals $1 / 8$ th of an acre.

2. The effect of the inclusion of more frequent visitors than the less frequent visitors in the on-site sampling is assumed to be small, as there were a larger number of respondents with the smallest number of trips to the study site. However, there is no significant change in welfare estimation while accounting for this effect (Ovaskainen et al., 2001).

3. The reference value of $\alpha$ (alpha) is $0.5>\alpha$ is unacceptable; $0.6>\alpha \geq 0.5$ poor, $0.7>\alpha \geq 0.6$ questionable; $0.8>\alpha \geq 0.7$ acceptable; $0.9>\alpha \geq 0.8$ good; $\alpha \geq 0.9$ excellent.

4. Due to political instability in the valley during last decade, the Jammu and Kashmir State tourism department could not update the tourism data properly. Based on the latest baseline study by Shah (2012), the data on tourist influx rate in 2008 to the Dal Lake was $10 \%$ of the whole tourists to Kashmir region. Therefore, we have approximated 10\% for Dal Lake of 2017 data for the Kashmir region.

5. In over-dispersed data, the variance is greater than mean because few visitors make many trips and most visitors make only a few.

\section{References}

Ahmedullah, M. (1997), Biodiversity of Jammu and Kashmir-A Profile, Indira Gandhi Conservation Monitoring Centre, World Wide Fund for Nature-India, 172-B, Lodi Estate, Max Mueller Marg, New Delhi.

Anand, A., Chandan, P. and Singh, R.B. (2012), "Homestays at Korzok: supplementing rural livelihoods and supporting green tourism in the Indian Himalayas", Mountain Research and Development, Vol. 32 No. 2, pp. 126-136.

Anonymous (1993), Directory of Indian Wetlands, World Wildlife Federation, New Delhi, p. 264.

Bakhsh, K., Meshaal, I. and Riaz, H. (2019), "Evaluating visitors' travel demand and recreational values in Kallar Kahar Lake, Pakistan”, Environment Development and Sustainability, Vol. 22 No. 8, pp. 7951-7967, doi: 10.1007/s10668-019-00555-6.

Barbier, E.B., Hacker, S.D., Kennedy, C., Koch, E.W., Stier, A.C. and Silliman, B.R. (2011), “The value of estuarine and coastal ecosystem services”, Ecological Monographs, Vol. 81 No. 2, pp. 169-193.
Recreational benefits of wetlands

$\longrightarrow$


Bassi, N., Kumar, M., Sharma, A. and Saradhi, P.P. (2014), "Status of wetlands in India: a review of extent, ecosystem benefits, threats, and management strategies", Journal of Hydrology: Regional Studies, Vol. 2 No. 1, pp. 1-19.

Basu, K. and Maertens, A. (2010), The Concise Oxford Companion to Economics in India, Published by Oxford University Press, p. 217.

Bell, F.W. and Leeworthy, V.R. (1990), "Recreational demand by tourists for saltwater beach days", Journal of Environmental Economics and Management, Vol. 18 No. 3, pp. 189-205.

Bhatt, S.M., Shah, A.S. and Abdullah, A. (2014), "Willingness to pay for preserving wetland biodiversity: a case study”, International Journal of Ecological Economics and Statistics, Vol. 35 No. 4, pp. 85-99.

Cameron, A.C. and Trivedi, P.K. (1998), Regression Analysis for Count Data, Econometric Society Monograph, Cambridge University Press, Cambridge, No. 30.

Chopra, K. (2004), "Economic valuation of biodiversity: the case of Keoladeo national park", in Gopal, K.K. (Ed.), Environmental Economics in Practice: Case Studies from India, Oxford University Press, New Delhi.

Cronbach, L.J. (1951), "Coefficient alpha and the internal structure of tests", Psychometrika, Vol. 16, pp. 297-334.

DeGroot, R.S., Stuip, M., Finlayson, M. and Davidson, N. (2006), "Valuing wetlands: guidance for valuing the benefits derived from wetland ecosystem services", Ramsar Technical Report No. 3/ CBD Technical Series No. 27, Ramsar Convention Bureau Gland Switzerland, available at: http://www.ramsar.org/pdf/lib/lib_rtr03.pdf (accessed 21 March 2015).

Do, Y., Ji, S.K., Kim, Y. and Joo, G. (2015), "Wetland-based tourism in South Korea: who, when, and why", Wetland Ecology and Management, Vol. 23 No. 4, pp. 779-787.

Du Preez, D.M. and Hosking, S.G. (2011), "The travel of the trout fishery at Rhodes, North Eastern Cape, South Africa: a travel analysis using Count Data models", Journal of Environmental Planning and Management, Vol. 52 No. 2, pp. 267-282.

Economic Survey (2017), Directorate of Economics and Statistics, Government of Jammu and Kashmir.

Edwards, P.E.T., Parson, G.R. and Myer, K.H. (2011), "The economic value of viewing migratory shorebirds on the Delaware Bay: an application of the single site Travel Cost Model Using onsite data", Working paper, Alfred Lerner of Business and Economics, Department of Economics, University of Delaware.

Garrod, G. and Willis, K.G. (1999), Economic Valuation of the Environment: Methods and Case Studies, Edward Elgar.

Gurluk, S. and Rehber, E. (2008), "A travel cost study to estimate recreational value for a bird refuge at lake manyas, Turkey", Journal of Environmental Management, Vol. 88 No. 3, pp. 1350-1360.

Islam, M.S., Howlader, A. and Islam, M.M. (2011), "Community-based ecotourism in the Sundarbans of Bangladesh”, Rajagiri Journal of Social Development, Vol. 3 Nos 1-2, pp. 31-50.

Jala and Nandagiri, L. (2015), "Evaluation of economic value of Pilikula Lake using travel cost and contingent valuation methods", Aquatic Procedia, Vol. 4, pp. 1315-1321.

Jeoffrey, D. and Sandrine, L. (2014), "Combining multivariate analysis and cost analysis in outdoor recreation planning", Journal of Outdoor Recreation and Tourism, Vol. 7 No. 8, pp. 75-88.

Karanth, K.K. and DeFries, R. (2011), "Nature-based tourism in Indian protected areas: new challenges for park management", Conservation Letters, Vol. 4 No. 2, pp. 137-149.

Khan, M.A. (2015), "Dal Lake of kashmir: problems, prospects, and perspectives", International Journal of Multidisciplinary Research and Development, Vol. 2 No. 2, pp. 462-469.

Kousmanen, T., Nillsen, E. and Wesseler, J. (2004), "Does ignoring multi-destination trips in the travel cost method cause a systematic bias?", The Australian Journal of Agricultural and Resource Economics, Vol. 48 No. 4, pp. 629-651. 
Kundangar, M.R.D. (2012), Squeezing Dal Lake-historical Perspective, Greater Kashmir 5th June, pp. 3-4.

Lamsal, P., Atreya, K., Pant, K.P. and Kumar, L. (2016), "Tourism and wetland conservation: application of travel cost and willingness to pay an entry fee at Ghodaghodi Lake Complex, Nepal", Natural Resources Forum, Vol. 40, pp. 51-61.

Recreational benefits of wetlands

Lawrence, W.R. (2005), The Valley of Kashmir, 2nd ed., Gulshan Books, Residency Road, Srinagar, p. 110001.

Lew, D.K. and Larson, D.M. (2005), "Valuing recreation and amenities at san Diego county beach", Coastal Management, Vol. 33, pp. 71-86.

Li, X., Yu, X., Hou, X., Liu, Y., Li, H., Zhou, Y., Xia, S., Liu, Y., Duan, H., Wang, Y., Dou, Y., Yang, M. and Zhang, L. (2020), "Valuation of wetland ecosystem services in national nature reserves in China's coastal zones", Sustainability, Vol. 12, p. 3131, doi: 10.3390/su12083131.

Mangan, T., Brouwer, R., Lohano, H.D. and Nagraj, G.M. (2013), "Estimating the recreational value of Pakistan's largest freshwater lake to support sustainable tourism management using a Travel Cost Model", Journal of Sustainable Tourism, Vol. 21 No. 3, pp. 473-486.

Martínez-Espiñeira, R. and Hilbe, J.M. (2008), "Effects on recreation benefit estimates from correcting for on-site sampling biases and heterogeneous trip overdispersion in count data recreation demand models (STATA)", Journal of Modern Applied Statistical Methods, Vol. 7 No. 1, pp. 331-345.

Martınez-Espineira, R. and Amoako-Tuffour, J. (2008), "Recreation demand analysis under truncation, overdispersion, and endogenous stratification: an application to Gros Morne national park", Journal of Environmental Management, Vol. 88 No. 4, pp. 1320-1332.

Meleddu, M. (2014), “Tourism, residents' welfare, and economic choice: a literature review”, Journal of Economic Survey, Vol. 28 No. 2, pp. 376-399.

Melichar, J. (2011), "Truncation, over-dispersion, and endogenous stratification in the recreation demand models", International Days of Statistics and Economics, Vol. 22 No. 23, pp. 390-402.

Okojie, L.O., Adewuyi, S.A. and Ijaola, A.A. (2013), "Demand for ecotourism recreation and welfare benefits in Obudu Cattle Ranch, Nigeria", American-eurasian Journal of Agricultural and Environmental Sciences, Vol. 13 No. 10, pp. 1375-1381.

Ortacesme, V., Ozkan, B. and Karaguzel, O. (2002), "An estimation of recreational use value of Kursunlu waterfall nature park by the individual travel cost method", Turkish Journal of Agriculture and Forestry, Vol. 26 No. 1, pp. 57-62.

Ovaskainen, V.J. and Mikkola, P.E. (2001), "Estimating recreation demand with on-site data: an application of truncated and endogenously stratified count data models", Journal of Forest Economics, Vol. 7 No. 2, pp. 125-144.

Pokki, H., Artell, J., Mikkola, J., Orell, P. and Ovaskainen, V. (2018), "Valuing recreational salmon fishing at a remote site in Finland: a travel cost analysis", Fisheries Research, Vol. 208, pp. 145-156.

Raina, M.Q. (2014), Kashur the Kashmiri-speaking People -analytical Perspective, Partridge Publisher, Haryana, India, 258, Sector 17, Panchkula-134109.

Rao, C. and Balasubramanian, R. (2017), "Recreational value of wetlands: the case of Kuttanad coastal wetland ecosystem of Kerala, India", International Journal of Current Microbiology and Applied Sciences, Vol. 6 No. 11, pp. 1753-1762.

Schuyt, K. and Brander, L. (2004), "The economic values of the world's wetlands, gland, Switzerland", World Wide Fund for Nature.

Shah, S.A. (2012), "Tourism and lake sustainabilit the economic values of the world's wetlands, gland, switzerlandy: a case study of Dal Lake", International Journal of Environmental Sciences, Vol. 1 No. 4, pp. 230-234.

Sheikh, A.H., Alam, A., Shah, A.M. and Bhat, S.A. (2008), "Land degradation modeling in Dal Lake catchment using geospatial tools", $W G$, pp. 89-169. 
Tapsuwan, S., Ingram, G. and Brennan, D. (2007), "Valuing urban wetlands of the gnangara mound: a hedonic property price approach in western Australia", Paper Presented at the Australian Agricultural and Resource Economics Society (AARES) 51st Annual Conference, Queenstown, Australia, 13-16th February.

Trisal, C.L. (1992), "Anthropogenic pressures and management of Dal Lake, kashmir”, in Chatrath, K.J.S. (Ed.), Wetlands of India, Ashish Publishing House, New Delhi, pp. 71-102.

Voltaire, L., Lévi, L., Alban, F. and Boncoeur, J. (2016), "Valuing cultural world heritage sites: an application of the travel cost method to Mont-Saint-Michel", Applied Economics, Vol. 49 No. 16, pp. 1593-1605.

Ward, F.A. and Beal, D. (2000), Valuing Nature with Travel Cost Methods, A Manual, Edward Elgar.

Wetlands Conservation and Management Rules (2017), available at: http://envfor.nic.in/sites/default/ files/Wetlands\%20(C\&M)\%20Rules, \%202017.pdf (accessed 20 March 2018).

Yousuf, T. and Ali, M. (2018), "Tourist satisfaction, environmental concerns, and tourism in and beyond Dal Lake, kashmir", Journal of Tourism and Hospitality, Vol. 7 No. 2, pp. 1-7.

Yrgalem, D. and Mekonnen, B. (2019), "Recreational use value of lakes an application of travel cost method: a case of lake Ziway", International Journal of Economy, Energy, and Environment, Vol. 4 No. 3, pp. 56-62.

Zarandi, M.T., Abesht, A., Abedi, S. and Ahangari, I. (2019), "The estimation of the economic value of wetland ecosystem protection and recreational services: a case study of Kanibrazan Wetland", International Journal of Materials and Environmental Sciences, Vol. 10 No. 11, pp. 1172-1184.

\section{Corresponding author}

Md. Saiful Islam can be contacted at: saifecon@yahoo.com

For instructions on how to order reprints of this article, please visit our website:

www.emeraldgrouppublishing.com/licensing/reprints.htm

Or contact us for further details: permissions@emeraldinsight.com 